


\title{
Writing Immigration
}

Scholars and Journalists in Dialogue

\author{
EDITED BY \\ Marcelo M. Suárez-Orozco \\ Vivian Louie \\ Roberto Suro
}

Ф

UNIVERSITY OF CALIFORNIA PRESS

Berkeley ' Los Angeles · London 
University of California Press, one of the most distinguished university presses in the United States, enriches lives around the world by advancing scholarship in the humanities, social sciences, and natural sciences. Its activities are supported by the UC Press Foundation and by philanthropic contributions from individuals and institutions. For more information, visit www.ucpress.edu.

University of California Press

Berkeley and Los Angeles, California

University of California Press, Ltd.

London, England

(C) $201 \mathrm{I}$ by The Regents of the University of California

Library of Congress Cataloging-in-Publication Data

Writing immigration : scholars and journalists in dialogue / edited by Marcelo M. Suárez-Orozco, Vivian Louie, and Roberto Suro.

p. $\mathrm{cm}$.

Includes index.

ISBN 978-0-520-26717-6 (cloth : alk. paper)

ISBN 978-0-520-267I 8-3 (pbk. : alk. paper)

I. United States-Emigration and immigration.

2. Emigration and immigration-Press coverage-

United States. I. Suárez-Orozco, Marcelo M., I956-

II. Louie, Vivian S. III. Suro, Roberto.

JV6465.W75 20II

$304.8^{\prime} 73$-dc22 2011006615

Manufactured in the United States of America

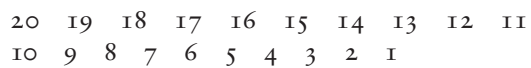

In keeping with a commitment to support environmentally responsible and sustainable printing practices, UC Press has printed this book on Rolland Enviroioo, a Io०\% post-consumer fiber paper that is FSC certified, deinked, processed chlorine-free, and manufactured with renewable biogas energy. It is acid-free and EcoLogo certified. 
For Howard Gardner 
